\section{Research Square}

Preprints are preliminary reports that have not undergone peer review.

They should not be considered conclusive, used to inform clinical practice, or referenced by the media as validated information.

\title{
Comparison of Student Performance, Self-mutual and Tutor Teaching Assessments in PBL Tutorial Process Between 1st and 4th Year Dental Undergraduates
}

\author{
Ting Zhou \\ Kunming Medical University Affiliated Stomatology Hospital \\ Yanjun Chen \\ Kunming Medical University Affiliated Stomatology Hospital \\ Rui Xu \\ Kunming Medical University Affiliated Stomatology Hospital \\ Chun Yang ( $\nabla$ yangchun68418@gmail.com) \\ Kunming Medical University https://orcid.org/0000-0002-6141-2629
}

\section{Research note}

Keywords: PBL, Dental undergraduates, Student performance evaluation, Self and mutual evaluation, Tutor teaching evaluation

Posted Date: February 5th, 2021

DOI: https://doi.org/10.21203/rs.3.rs-185432/v1

License: () (1) This work is licensed under a Creative Commons Attribution 4.0 International License. Read Full License 


\section{Abstract}

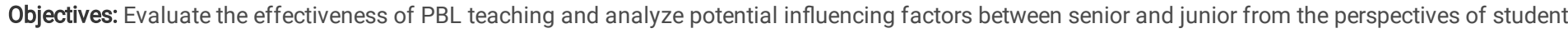
performance, student self-mutual and tutor teaching evaluations.

Results: Study found the overall three comparative assessments scores of Grade 4 were significantly higher than those of Grade $1(P \otimes 0.01)$. Further analysis revealed no significant difference of student performance score between Grade 4 and Grade 1 in the 1 st unit ( $P \otimes 0.05)$, but it was improved and maintained significantly since 2 nd time ( $P \otimes 0.01)$.Moreover, each self-mutual evaluation of 4 th year students was significantly higher than that of $1 \mathrm{st}$ year students, especially in the second half of the course $(P \otimes 0.01)$.And, all the evaluations of tutor teaching from seniors were significantly higher than those from juniors $(P$ 0.01). Finally, no significant correlation between student self-mutual scores and those given by tutors no matter high or lower grade ( $P \otimes 0.05)$.

\section{Introduction}

PBL (Problem-based Learning) has quickly become a continuous hot issue of medical education reform [1-3] due to its unique advantages in concepts, models, and ability training effects [4] since being introduced into the medical education field of China. As a student-centered and problem-oriented group discussion mode of learning [5], the attribute of this provides an encouraging way of learning because students can deal with challenging and observed problems in real life [6], as promoting them to realize the value of solving and understanding problems [7]. Therefore, an integrated PBL course aimed at improving students' ability of combining clinical thinking with practice was developed for the 4th year undergraduates in school of Stomatology, Kunming Medical University since 2015, and a good teaching outcome was obtained [8]. In succession, a pilot PBL teaching was also conducted among the Grade 1 students.

Sufficient literatures showed that PBL was very effective for dental education $[6,9,10]$, the critical thinking, analysis and problem-solving skills of dental students were improved through PBL. However, using effective and reliable strategies to evaluate the overall performance of students is one of the main challenges of PBL teaching $[11,12]$.

The study intended to evaluate the effectiveness of PBL teaching and analyze potential influencing factors between high and low grades from the perspectives of student performance, student self and mutual evaluation and tutor teaching evaluation.

\section{Materials And Methods General information}

81 Grade 1 and 83 Grade 4 students of dental school, Kunming Medical University participated in PBL teaching at Spring and Fall semester in the year 2018, respectively. The details of PBL teaching about two grades were summarized in Table 1. 
Table 1

PBL course information (contents, class hours, tutors background)

\begin{tabular}{|c|c|c|}
\hline & 1 st year & 4th year \\
\hline $\begin{array}{l}\text { Course } \\
\text { adopted PBL } \\
\text { teaching }\end{array}$ & Introduction of Stomatology & Comprehensive training of dental clinical skills \\
\hline $\begin{array}{l}\text { Academic } \\
\text { Year }\end{array}$ & 1st Year (2nd Semester) & 4th Year (7th Semester) \\
\hline \multirow[t]{3}{*}{ Class hours } & Totally 36 class hours & Totally 90 class hours \\
\hline & $\begin{array}{l}\text { - First } 24 \text { class hours of } \\
\text { conventional lectures }\end{array}$ & - 60 class hours of PBL group discussion \\
\hline & $\begin{array}{l}\text { - Last } 12 \text { class hours of PBL } \\
\text { group discussion }\end{array}$ & - 30 class hours of skills practice \\
\hline PBL Units & 1 & 5 \\
\hline $\begin{array}{l}\text { Tutors number } \\
\text { (background) }\end{array}$ & $\begin{array}{l}\text { Totally } 8 \\
\text { (Medical background) }\end{array}$ & $\begin{array}{l}\text { Totally } 20 \text { (Medical background), including the same } 8 \text { tutors of } 1 \text { st year students; Tutors instructed } \\
\text { each group randomly, and then be assigned to the new group after each unit finished. }\end{array}$ \\
\hline
\end{tabular}




\begin{tabular}{|c|c|c|}
\hline & 1st year & 4th year \\
\hline Main & 1. Humanistic education & 1. Emphasizing the integration of disciplines, \\
\hline \multirow[t]{32}{*}{ Contents } & \multirow{6}{*}{$\begin{array}{l}\text { - Doctor-patient } \\
\text { communication skills } \\
\text { - Humanistic care in } \\
\text { doctor-patient communication } \\
\text { - Rationality of } \\
\text { toothpaste advertisements }\end{array}$} & focusing on "etiology-mechanism-clinical \\
\hline & & manifestations-diagnosis- treatment" of \\
\hline & & common dental clinical diseases. \\
\hline & & - Endodontics \\
\hline & & - Periodontics \\
\hline & & - Oral and maxillofacial surgery \\
\hline & \multirow{2}{*}{ - Psychological characteristics } & - Prosthodontics \\
\hline & & - Orthodontics \\
\hline & \multirow{2}{*}{$\begin{array}{l}\text { and behavior patterns of } \\
\text { Chinese people when they are } \\
\text { sick }\end{array}$} & - Preventive Dentistry \\
\hline & & - Pediatric Dentistry \\
\hline & - The psychological & - Oral Implantology \\
\hline & effects of gingivitis & - Oral Anatomy and Physiology \\
\hline & $\begin{array}{l}\text { 2. Common oral problems in } \\
\text { life }\end{array}$ & - Oral Histopathology \\
\hline & \multirow{2}{*}{$\begin{array}{l}\text { - General procedures of } \\
\text { orthodontic treatment }\end{array}$} & 2. Humanistic education and others \\
\hline & & - Responsibility system for the first \\
\hline & $\begin{array}{l}\text { - Clinical manifestations of } \\
\text { gingivitis }\end{array}$ & consultation \\
\hline & • Fixed appliance & - Consultation system \\
\hline & - Complications of & - The performance and strategy of doctors' \\
\hline & orthodontic treatment & humanistic care \\
\hline & \multirow{2}{*}{$\begin{array}{l}\text { - Causes of proliferative } \\
\text { gingivitis }\end{array}$} & - Reasons for lack of early diagnosis and treatment, from perspective of sociology \\
\hline & & - Doctor-patient communication strategies for \\
\hline & \multirow[t]{11}{*}{$\begin{array}{l}\text { - Normal physiological } \\
\text { structure of periodontal tissue }\end{array}$} & multiple failures in medical treatment \\
\hline & & - Preoperative communication \\
\hline & & •Informed consent \\
\hline & & - Medical ethics and humanistic care \\
\hline & & • Status of "difficult to get medical treatment" \\
\hline & & - Necessity and standardization of case \\
\hline & & follow-up system \\
\hline & & - How does humanistic care be reflected in the process of doctor-patient diagnosis and \\
\hline & & treatment \\
\hline & & - Importance and significance of oral health education and patient compliance \\
\hline & & - Safety in school-prevention of dental trauma during exercise \\
\hline
\end{tabular}

\section{Evaluation methods and calculation}

Standard PBL process were adopted both in 2 grades. The PBL scales originated from dental school, Wuhan University, China were applied at the 3rd time discussion of each unit, so the data of above evaluations were obtained one time from Grade 1 but 5 times form Grade 4, which including student performance, student self - mutual and tutor teaching evaluations.

- Student Performance Evaluation: Tutors score students; PBL student self-evaluation and mutual evaluation: students score themselves and their peers; Tutor teaching evaluation: Students score tutors.

- In the comparison of self- mutual evaluation between two grades, the scores compared were the initial scores of students evaluating themselves and their peers; When correlation between student self -mutual evaluation and student performance evaluation was tested, the individual score was calculated and applied.

- The Tutor teaching evaluation of Grade 4 only counted the scores of same 8 tutors with Grade 1. 


\section{Statistics}

A commercially available software program (SPSSAU) were performed for analysis. P-value $<0.05$ was considered significant statistically. Descriptive data, including mean \pm standard deviation and (median) were used for expression of each evaluated scores. Kolmogorov-Smirnov test was used to detect whether the quantitative data were normally distributed.

- Mann-Whitney U test was used for the overall comparison of three evaluation scores between two grades.

- Kruskal-Wallis test and Dunn test were used for the comparison of assessments in different grades and times. $\lambda$

- Spearman correlation was tested between student self-mutual evaluation (Individual score after calculation) and student performance evaluation

\section{Results}

\section{Overall comparison of three evaluation scores between two grades}

All the three comparative assessments of Grade 4 obtained significantly higher scores (Table 2).

\section{Comparison of assessments in different units}

Firstly, no significant difference of student performance score between 1 st unit of Grade $4(39.55 \pm 3.82)$ and Grade 1 (39.16 \pm 4.12$)$, but the scores were improved significantly and maintained since 2nd time PBL of Grade 4 (Table 2).

Secondly, any student self-mutual and tutor teaching evaluation result of 4th year students was significantly higher than that of 1 st year students, and the scores of last 3 times were significantly higher than those of first 2 times (Table 2). 
Table 2

Comparison of three assessments both overall and different times

\begin{tabular}{|c|c|c|c|}
\hline & Student performance evaluation & $\begin{array}{l}\text { Student self and } \\
\text { mutual evaluation }\end{array}$ & Tutor teaching evaluation \\
\hline \multicolumn{4}{|l|}{ Overall } \\
\hline \multirow[t]{2}{*}{ Grade 1} & $\mathrm{n}=81$ & $\mathrm{n}=81$ & $\mathrm{n}=81$ \\
\hline & $39.16 \pm 4.12(40.000)$ & $91.93 \pm 3.52(91.550)$ & $97.20 \pm 2.64(98.000)$ \\
\hline \multirow[t]{2}{*}{ Grade 4} & $\mathrm{n}=415$ & $\mathrm{n}=406$ & $\mathrm{n}=182$ \\
\hline & $41.18 \pm 2.61(41.700)$ & $98.62 \pm 0.67(98.600)$ & $99.05 \pm 1.6(100.0)$ \\
\hline$P$ value & $0.002^{\star \star}$ & $0.000 * \star$ & $0.000 * *$ \\
\hline \multicolumn{4}{|c|}{ Different units } \\
\hline \multirow{2}{*}{$\begin{array}{l}\text { Grade } \\
1(\mathrm{~T} 1)\end{array}$} & $n=81$ & $\mathrm{n}=81$ & $n=81$ \\
\hline & $39.16 \pm 4.12(40.000)$ & $91.93 \pm 3.52(91.550)$ & $97.20 \pm 2.64(98.000)$ \\
\hline \multicolumn{4}{|l|}{ Grade 4} \\
\hline \multirow{2}{*}{$\begin{array}{l}\text { 1st time } \\
\text { (T4-1) }\end{array}$} & $n=83$ & $n=83$ & $n=47$ \\
\hline & $39.55 \pm 3.82(40.000)$ & $97.93 \pm 0.87(97.890)$ & $98.72 \pm 1.87(99.000)$ \\
\hline \multirow{2}{*}{$\begin{array}{l}\text { 2nd } \\
\text { time(T4- } \\
\text { 2) }\end{array}$} & $n=83$ & $n=83$ & $n=36$ \\
\hline & $42.00 \pm 3.24(42.000)$ & $98.52 \pm 0.79(98.330)$ & $98.67 \pm 2.04(100.000)$ \\
\hline \multirow{2}{*}{$\begin{array}{l}\text { 3rd } \\
\text { time(T4- } \\
3)\end{array}$} & $n=83$ & $n=83$ & $n=27$ \\
\hline & $41.69 \pm 4.98(43.000)$ & $98.81 \pm 0.68(98.890)$ & $99.26 \pm 1.51(100.000)$ \\
\hline \multirow{2}{*}{$\begin{array}{l}\text { 4th } \\
\text { time(T4- } \\
\text { 4) }\end{array}$} & $n=83$ & $n=83$ & $\mathrm{n}=38$ \\
\hline & $41.36 \pm 2.88(42.000)$ & $99.00 \pm 0.73(99.000)$ & $99.37 \pm 1.00(100.000)$ \\
\hline \multirow{2}{*}{$\begin{array}{l}\text { 5th } \\
\text { time(T4- } \\
5)\end{array}$} & $n=83$ & $n=74$ & $n=34$ \\
\hline & $41.33 \pm 4.41(42.000)$ & $98.84 \pm 0.64(98.750)$ & $99.41 \pm 1.42(100.0000)$ \\
\hline \multirow[t]{2}{*}{$P$ value } & $0.000 * \star$ & $0.000 \star \star$ & $0.000 * \star$ \\
\hline & 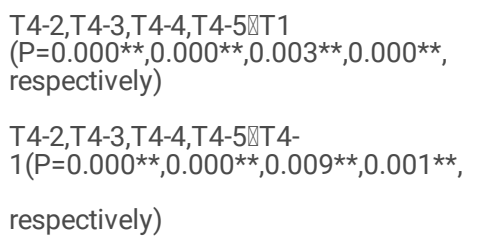 & 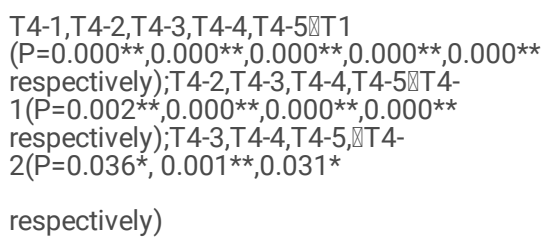 & 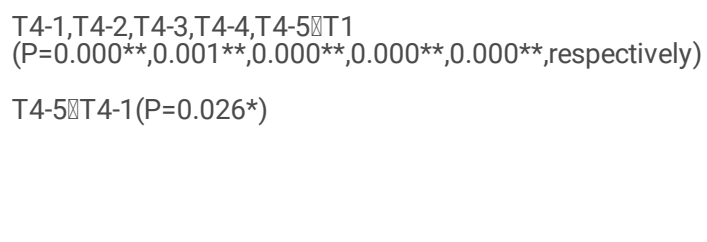 \\
\hline
\end{tabular}

\section{Correlation between student self-mutual and student performance}

Low correlation coefficient were found in a total of 6 times evaluations of two grades, no significant correlation between student self-mutual and student performance scores from tutors (table 3).

Table 3

Spearman correlation between student self-mutual evaluation (Individual score after calculation) and student performance evaluation

\begin{tabular}{|c|c|c|c|c|c|c|}
\hline \multirow[b]{2}{*}{ Student self and mutual evaluation (Individual score after calculation) } & \multicolumn{6}{|c|}{ Student performance evaluation from tutors } \\
\hline & Grade 1 & Grade 4 & & & & \\
\hline & & 1st unit & 2nd unit & 3rd unit & 4th unit & 5th unit \\
\hline & 0.164 & 0.020 & 0.048 & 0.121 & 0.060 & -0.193 \\
\hline$P$ value & 0.144 & 0.854 & 0.669 & 0.276 & 0.589 & 0.100 \\
\hline
\end{tabular}

\section{Discussion}


Evaluation plans and strategies consistent with the purpose of the PBL curriculum were strongly advocated [13, 14]. The assessment was driven by the demand for constructive adjustment between intentions and evaluations of PBL, the conventional summative assessment model was not really fit well to PBL [15]. Hence, the formative assessment protocols including student performance, student self-mutual evaluation and tutor teaching evaluation were adopted in this study, which provide unique opportunity to judge each other's work between tutors and students wherefore making them develop the ability to reflect on own strengths and weaknesses as these are central elements of self-directed learning (SDL) [16].

PBL was assumed to promote other abilities than knowledge and skills, such as collaboration, communication and regulated learning ability and professionalism [15].

The result of exceeding average 2 points, equivalent to 4 points in a hundred marks system, showed Grade 4 students received higher overall student performance ratings, it was learned from tutor's feedback that senior students have demonstrated obviously improved self-directed learning (SDL)capabilities, which was manifested as more adequate preparation, more eye-catching communication and expression in the discussion process. Elzubeir MA's research [17] found that senior students had statistically significantly higher mean scores on 11 of 14 self-assessed SDL competencies ( $p<0.05)$ in comparison to junior students. Yet it was noted that no difference between points of $39.16 \pm 4.12(40.000)$ from Grade 1 and $39.55 \pm 3.82(40.000)$ from Grade 4 in the first unit of PBL. Under the conditions of first attempt, this is very likely related to the writing of the problem scenarios and the teacher's guidance. Undoubtedly, the preparation of problem scenarios is the focus of learning and the framework of discussion [18]. In our study, all the problem scenarios were compiled after collective discussion by all tutors instead of the existing cases of other schools. Therefore, it was mainly focus on humanistic education and common oral problems in life for 1 st year students but emphasizing the integration of "etiology-mechanism-clinical manifestations-diagnosis-treatment" of common dental clinical diseases for Grade 4. Taking into consideration of characteristics of teaching subjects to set more targeted problem scenarios may weaken the difference in knowledge and skill discrepancy between the higher and lower grade to a certain extent. In addition, all tutors who serve as the first grade were selected from last round of PBL teaching and that their own experienced skills may also play a positive role in guiding first year students. For example, tutors can strengthen the interaction of tutor and student by asking questions so as to facilitate students to express themselves more actively [19]. The above two keys were also positively affirmed by the interviews with students when course finished.

A basic part of the PBL process is that students are responsible for being active members of a group of learners. This may include the practice of collaboration and self-assessment, which may enhance reflection and self-awareness [20]. More than 90 scores of self-mutual evaluation were observed both in 2 grades, especially the fourth year students, all scores were above 95 points. Compared with Grade 1, the senior students gave themselves and their peers significantly higher self-mutual scores from the beginning of PBL, and this reached peaks at the middle and late stages of the course (Table 2), this may mainly depend on the following factors: first of all, the time point of PBL course for 4th year students was set after completion of all basic and clinical courses of Dentistry and before students entering the clinical practice. On the one hand, senior students have mastered a certain professional knowledge after 3-year studying, the implementation of PBL just cater to the demands for combination of theory into practice, which was likely to more attractive to students. All above were the foundations and conditions that 1st students can't possess. Hagi SK's research [21] revealed that a positive and higher mean score was found in all statements of the questionnaire about students' perception of PBL in the new curriculum among fourth year medical students than those of second year students. And, regardless of high or low grade, students scored themselves and peers generously, always above their tutor's marks, which were similar with Machado JL's study [22].In addition, there was no significant correlation between student self-mutual evaluation and scores from tutors, the correlation coefficient for Grade 1 was 0.164 , and those of 5 assessments for Grade 4 was $0.020,0.048,0.121,0.060,-0.193$, respectively (table3), this may be caused by inconsistent evaluation standards and lack of transparency in procedures [22] between students and tutors, similar results have been reported in previous research $[20,23,24]$. Nevertheless, the high grade of self- mutual evaluation also reflects the efforts of students in the teaching process, because it still plays an important role in supporting reflection and self-awareness skills development [20].

The tutor's framing of active student learning and building on knowledge is an decisive factors of successful implementation of PBL [6]. However, the repositioning of the role of tutor remains challenges all the time due to it occupies a central and unique role in influencing students' learning [25]. Student assessment information speaks to the outcomes of the educational process, and often serve as benchmarks for comparison and formative assessment for teachers [26]. The same 8 tutors received higher ratings from Grade 4 students, this showed that the acceptance of the new role of teachers in PBL teaching by the students in the first grade was lower than that of fourth grade students. Yet, it was not difficult to find that the average score of teacher evaluation was $97.20 \pm 2.64$ (98.000) but $91.93 \pm 3.52(91.550)$ for themselves and their peers in Grade 1, indicating that the recognition of tutors by Grade 1 students was still very high. Therefore, in addition to the consciousness of students, the potential influencing factor may depend on the expertise of tutors. Indeed, there is no doubt about the ability of the medical teaching team in terms of professional quality, but the comprehensive ability of multidisciplinary knowledge and the integration of medical science with other social sciences such as the Humanities was not enough, the study observed the existence of differences between medical tutors and non-medical tutors in facilitating the group process [19]. Tutors with expertise tended to serve as a more directive role, spoke more often and for longer, provided more direct answers and suggested more discussion topics in the tutorial [27], which may play a positive but negative role of promoting the group process in 4th and 1 st year students, respectively.

\section{Limitation}

- This study was only pilot PBL teaching being carried out for first year students, that evaluation based on one unit (12 hours) may cause biased results, such as the performance of students may be improved in the following teaching units after the initial attempt, and lack of opportunities for more interaction with tutors for 1 st year students.

- In addition, the results reflected the differences in scores, but didn't reveal the specific crux of the differences.

\section{List Of Abbreviations}


PBL (Problem-based Learning) SDL (self-directed learning)

\section{Declarations}

Ethics approval and consent to participate

Not applicable

\section{Consent for publication}

Not applicable

\section{Availability of data and material}

The datasets used and/or analysed during the current study are available from the corresponding author on reasonable request.

\section{Competing interests}

The authors declare that they have no competing interests

\section{Funding}

Consultation and data analysis of this work were supported by Yunnan Science and Technology Department-Kunming Medical University Applied Basic Research Joint Fund, grant number囚2019FE001-090囚

\section{Author's contributions}

Conceptualization: Chun Yang

Formal Analysis: Ting Zhou

Acquisition of data: Yanjun Chen, Rui Xu

Methodology: Ting Zhou, Yanjun Chen

Project Administration: Chun Yang

Writing-Original Draft: Yanjun Chen

Writing-Review \& Editing: Ting Zhou, Chun Yang

\section{Acknowledgements}

Thanks for the Intellectual support from Yi Peng, Rui She, Yanhong Li, Xingxing Li, and all PBL teaching team members of dental school, Kunming Medical University.

\section{References}

1. Jia X, Zeng W, Zhang Q. Combined administration of problem- and lecture-based learning teaching models in medical education in China: A meta-analysis of randomized controlled trials. Medicine (Baltimore). 2018 Oct;97(43):e11366.

2. Ma Y, Lu X. The effectiveness of problem-based learning in pediatric medical education in China: A meta-analysis of randomized controlled trials. Medicine (Baltimore). 2019 Jan;98(2):e14052.

3. Liu CX, Ouyang WW, Wang XW, Chen D, Jiang ZL. Comparing hybrid problem-based and lecture learning (PBL $+\mathrm{LBL})$ with $L B L$ pedagogy on clinical curriculum learning for medical students in China: a meta-analysis of randomized controlled trials. Medicine (Baltimore). 2020 Apr;99(16):e19687.

4. Qin, Y., Y. Wang and R.E. Floden, The Effect of Problem-Based Learning on Improvement of the Medical Educational Environment: A Systematic Review and Meta-Analysis. Med Princ Pract, 2016. 25(6): p.525-532.

5. D A Kilory.Problem based learning[J].Emerg M ed,2004,21(11):411-413.

6. Alrahlah A. How effective the problem-based learning (PBL) in dental education. A critical review. Saudi Dent J. 2016 Oct;28(4):155-161.

7. Barrows, H., 2002. Is it truly possible to have such a thing as d PBL? Distance Educ. 23 (1), 119-122.

8. ZHOU Ting, CHEN Yan-jun, XU Rui, YANG Chun. Evaluation of Teaching Effect of Stomatology Curriculum Reform. [J] Journal of Kunming Medical university. 2020,41(04):161-166.

9. Huang B, Zheng L, Li C, Li L, Yu H. Effectiveness of problem-based learning in Chinese dental education: a meta-analysis. J Dent Educ. 2013 Mar;77(3):377-83.

10. Al-Madi EM, Celur SL, Nasim M. Effectiveness of PBL methodology in a hybrid dentistry program to enhance students' knowledge and confidence. (a pilot study). BMC Med Educ. 2018 Nov 20;18(1):270. 
11. Epstein RM. Medical education - assessment in medical education. N Engl J Med. 2007;356:387-396.

12. Sahoo S, Myint KT, Soe HHK, et al. Formative assessment of ophthalmology problem-based learning tutorials during undergraduate medical training. Asia-Pacific J Ophthalmol. 2013;2:282-285.

13. Nendaz MR, Tekian A. Assessment in problem-based learning medical schools: a literature review. Teach Learn Med. 1999;11:232-243.

14. Yaqinuddin A, Kvietys P, Ganguly P, et al. PBL performance correlates with content acquisition assessment:a study in a hybrid PBL program at Alfaisal University. Med Teach. 2012;34:83.

15. van der Vleuten CPM, Schuwirth LWT. Assessment in the context of problem-based learning. Adv Health Sci Educ Theory Pract. 2019 Dec;24(5):903-914.

16. Eva KW, Cunnington JPW, Reiter HI, Keane DR, Norman GR. 2004. How can I know what I don't know? Poor self assessment in a well-defined domain. Adv Health Sci Edu 9:211-224.

17. Elzubeir MA. Graduate-entry medical students' self-directed learning capabilities in a problem-based curriculum. Saudi Med J. 2009 Sep;30(9):1219-24.

18. Peavy DE. A new PBL case-writing course. Acad Med. 2001 Feb;76(2):108-9.

19. Gilkison A. Techniques used by "expert" and "non-expert" tutors to facilitate problem-based learning tutorials in an undergraduate medical curriculum. Med Educ. 2003 Jan;37(1):6-14.

20. Papinczak T, Young L, Groves M, Haynes M. An analysis of peer, self, and tutor assessment in problem-based learning tutorials. Med Teach. 2007 Jun;29(5):e122-32.

21. Hagi SK, Al-Shawwa LA. Evaluation of second and fourth year undergraduate medical students' perception and acceptance of the problem-based learning process. Saudi Med J. 2011 Oct;32(10):1060-5.

22. Machado JL, Machado VM, Grec W, Bollela VR, Vieira JE. Self- and peer assessment may not be an accurate measure of PBL tutorial process. BMC Med Educ. 2008 Nov 27;8:55.

23. Sluijmans DMA, Moerkerke G, van Merrienboer JJG, Dochy FJRC. Peer assessment in problem-based learning. Stud Edu Eval. 2001;27:153-173.

24. Reiter HI, Eva KW, Hatala RM, Norman GR. Self and peer assessment in tutorials: Application of a relative-ranking model. Acad Med. 2002;77:1134-1139.

25. Chan LC. The role of a PBL tutor: a personal perspective. Kaohsiung J Med Sci. 2008 Mar;24(3 Suppl):S34-8.

26. Norcini J, Anderson MB, Bollela V, Burch V, Costa MJ, Duvivier R, Hays R, Palacios Mackay MF, Roberts T, Swanson D. 2018 Consensus framework for good assessment. Med Teach. 2018 Nov;40(11):1102-1109.

27. Silver M, Wilkerson L. Effects of tutors with subject expertise on the problem-based tutorial process. Acad Med1991;66:298-300.

\section{Supplementary Files}

This is a list of supplementary files associated with this preprint. Click to download.

- renamed5565d.docx

- Fig1.tif

- Fig2.tif

- Fig3.tif

- Fig4.tif

- Fig5.tif

- Fig6.tif 